\title{
Konference mladých slavistů v Hamburku 2019
}

Od 18. do 20. září 2019 se konala dvacátá osmá konference mladých slavistů z německojazyčných zemí, a to na Ústavu slavistiky Hamburské univerzity. Organizátorem setkání byl Martin Henzelmann z domácího Ústavu slavistiky. Akce se mohla konat díky štědré finanční podpoře od vědecké nadace Hamburgische Wissenschaftliche Stiftung.

Mladí slavisté jsou neformální organizací mladých badatelů, kteří se setkávají každým rokem na podzim. Na těchto každoročních konferencích, konaných na různých univerzitách $\mathrm{v}$ Německu, jsou představovány výsledky výzkumu v různých oborech slovanské jazykovědy. Účastníci jsou (post)doktorandi, a jsou tedy na počátku své vědecké kariéry $\mathrm{v}$ humanitních vědách, zejména ve slavistice. Jejich příspěvky z různých oblastí slovanské filologie jsou následně publikovány ve sbornících. Byla zprovozněna také internetová stránka (<http://jungslavisten.de/>), na níž se zájemci mohou o aktivitách mladých německých slavistů dozvědět více informací.

V Hamburku se konference mladých slavistů konala naposledy v roce 1994. Proto bylo rozhodnuto, že po čtvrtstoletí bude právě Hamburk znovu vybrán jako místo konání. Tímto způsobem byl zároveň připomenut význam hamburského Ústavu slavistiky pro mladé slavistické badatele.

I letos byly na konferenci představeny referáty týkající se značně rozmanitých témat z východoslovanského, západoslovanského i jihoslovanského jazykového prostoru. Kromě toho byly předmětem úvah i problémy jazykovědy srovnávací.

Problematice východoslovanských jazyků se věnovalo sedm referátů, konkrétně byly předneseny příspěvky o kvantitativním výzkumu lingvistického prostředí v Minsku (Alisa Müller, Bamberk), konceptualizaci stáří z kontrastivně-diskurzivního jazykového hlediska (Valeria Wagner, Hamburk), valenční struktuře sloves u mluvčích s ruštinou jako mateřským jazykem (Veronika Wald, Řezno), ruštině v terciárním vzdělávání v Německu (Ksenija Vossmiller, Hildesheim) a konečně o tzv. indikátorech při čtení a sledování pohybu očí (Nelli Ritter, Hamburk). V oboru ukrajinistiky byla prezentována studie o politické instrumentalizaci jazyka na východní Ukrajině (Marianna Novosolova, Dráždany) a analýza tvorby Pantelejmona Kuliše a vytvoření ukrajinského biblického stylu (Ruben Biewald, Gießen).

Přednášky z oblasti západoslovanských jazyků se věnovaly následujícím tématům: populární hudba v Horním Slezsku a její pramenný význam pro jazykovědce (Irenäus Kulik, Göttingen) a výsledky empirického výzkumu slovosledu přídavných jmen v polštině (Christina Clasmeier, Bochum). 


\section{Hamburgische
Wissenschaftliche
Stiftung ||||}

Badatelé zabývající se jihoslovanskými jazyky se věnovali následujícím otázkám: rozlišení mezi imperfektem a aoristem $\mathrm{v}$ bulharštině (Hagen Pitsch, Göttingen), národ $\mathrm{v}$ genderových diskusích bývalého

srbochorvatského jazykového prostoru (Simone Rajilić, Berlín) a současné lexikografické výzvy u bunjevců v Srbsku (Martin Henzelmann, Hamburk).

Vícejazyčnou perspektivou se zabývali ve svých př́spěvcích čtyři badatelé, a to $\mathrm{v}$ referátech na témata: překlad, slovanské jazyky a cesta ke korpusu (Petr Biskup, Lipsko), vlastnosti neosobních konstrukcí ve východoslovanských a západoslovanských jazycích (Anastasia Bauer, Kolín nad Rýnem), jazykovědný rozbor př́padu Aleca Holowky (Nicolas Jansens, Heidelberg) a vliv slovanských jazyků na morfologii slovesa v romštině (Anna-Maria Meyer, Kolín nad Rýnem).

Hlavní pořadatel by touto cestou znovu rád poděkoval nadaci Hamburgische Wissenschaftliche Stiftung za velkorysou finanční podporu, jež umožnila zorganizovat konferenci $\mathrm{v}$ dané podobě. Zpráva o tomto slavistickém setkání bude zároveň uveřejněna v německém časopise Zeitschrift für Slawistik. Sborník s konferenčními prríspěvky bude publikován v brzké době.

Martin Henzelmann

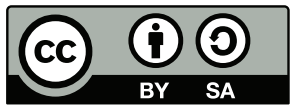

Toto dílo lze užít v souladu s licenčními podmínkami Creative Commons BY-SA 4.0 International (<https:// creativecommons.org/licenses/by-sa/4.0/legalcode>). Uvedené se nevztahuje na díla či prvky (např. obrazovou či fotografickou dokumentaci), které jsou v díle užity na základě smluvní licence nebo výjimky či omezení príslušných práv. 